\title{
Seroprevalence and Risk Factors for Toxoplasmosis in the Cows (Cattle), Bos indicus Linnaeus (Mammalia: Eutheria) from Dir Upper, Khyber Pakhtunkhwa, Pakistan
}

\author{
Perveen FK* and Shah $\mathrm{H}$ \\ Department of Zoology, Shaheed Benazir Bhutto University, Pakistan
}

\section{Research Article}

Volume 1 Issue 3

Received Date: September 08, 2016

Published Date: October 19, 2016

*Corresponding author: Farzana Khan Perveen, Founder Chairperson and Associate

Professor, Department of Zoology, Shaheed Benazir Bhutto University (SBBU), Main Campus, Sheringal, Dir Upper (DU), Khyber Pakhtunkhwa (KP), Pakistan, Tel: +92-944885415; E-mail: farzana_san@hotmail.com

\section{Abstract}

Toxoplasma gondii (Nicole and Manceaux, 1908) (Apicomplexa: Coccidia) is an obligate intracellular protozoan parasite, causing toxoplasmosis in humans and cattle worldwide. In the current research, seroprevalence and risk factors for toxoplasmosis in the cows (cattle), Bos indicus Linnaeus 1758 (Mammalia: Eutheria) of Dir Upper (DU), Khyber Pakhtunkhwa (KP), Pakistan were determined. Bos indicus $\left(\mathrm{n}_{\mathrm{t}}=250\right)$ including males $\left(\mathrm{n}_{\text {male }}=86\right)$ and females $\left(\mathrm{n}_{\text {female }}=164\right)$ were tested for the presence of antibodies against T. gondii using Latex Agglutination Test kit ${ }^{\circledR}$. Agglutination at 1:16 dilution was considered positive. A $14 \%$ overall prevalence was recorded. The antibody titers to T. gondii positive (apparent prevalence) sera were 10\%,2\%,1\% and $0 \%$ by dilution of 1:16, 1:32, 1:64 and 1:128, respectively, but true prevalence, for male, female and total were $0.536 \%, 0.514 \%$ and $0.525 \%$, respectively. However, males were found more infected (16\%) compared to females (12\%). Moreover, the highest rate (16\%) of infection was recorded in the 1-4 years age range, while the lowest (7\%) was in the 5-8 years range. However, no significant correlation was found between toxoplasmosis and sex/age. Furthermore, infection was the highest (25\%) in B. indicus with 5 pregnancies and no abortion was observed in infected B. indicus. In addition, presence of cats, Felis catus Linnaeus, in households, source of drinking water and type of management of $B$. indicus resulted to be important risk factors. In conclusion, toxoplasmosis is prevalent in B. indicus in DU. Prompt control measures and public awareness is recommended to lower the risk of infection with T. gondii.

Keywords: Bos indicus; Dir Upper, Seroprevalence; Toxoplasma gondii; Toxoplasmosis

\section{Introduction}

Toxoplasma gondii (Eucoccidiorida: Sarcocystidae) is an obligate intracellular protozoan, which causes infection called toxoplasmosis in birds and mammals. The parasite is distributed throughout the world and infects about one third of human population [1]. Felids, especially domestic cats, Felis catus Linnaeus, 1758, are the main reservoir for T. gondii [2]. Besides causing problems in humans, the parasite also adversely affects the production of livestock [3]. Generally, the cows (cattle), Bos indicus Linnaeus 1758 (Artiodactyla: 
Bovidae) are considered resistant to toxoplasmosis but still, both experimental and natural infections have been reported in them [4]. However, infection is more common in calves than in adults. Moreover, infected by oral route, they may show the clinical signs of diarrhea, anorexia, low weigh gain, weakness, depression, dyspnea and fever. Sometimes, the lymph nodes may also become infected. Further, stillbirth and death of neonates also results in case of congenital toxoplasmosis [5]. Furthermore, infection in cattle also has the potential to transmit the disease to humans and other animals. Consequently, studies have shown that the consumption of raw beef and milk pose a risk for human toxoplasmosis [3]. In addition, the parasitic zoonotic diseases, which are transmitted by ingestion of meat, create health problems throughout the world causing significant losses to the economy. Although, little success has been achieved in controlling these infections especially in developing countries. An important factor which may contribute to the spread of disease is the failure to detect T.gondii in meat, whereas, the tissue cysts containing the infectious bradyzoites are widely prevalent in various tissues of livestock animals. When humans consume the raw or undercooked meat, the infection can be transmitted from these animals to humans through the tissue cysts [6].

In humans, more research has been carried out on congenital toxoplasmosis; however, little attention has been paid to the role of horizontal transmission in disease dissemination. Therefore, there is a need to identify the main routes of transmission and develop strategies for control and prevention of the infection. Moreover, it is essential to identify the risk factors associated with acquisition of toxoplasmosis in animals used for human consumption, because this will help to create methods for rearing of animals that will promote the control and prevention of disease in these animals. Further, this will lead to the production of parasite-free meat for human consumption [7].

In Pakistan, there is a close contact between humans and livestock, therefore, toxoplasmosis is of special significance and requires a thorough investigation [8]. However, data regarding the incidence and prevalence of toxoplasmosis in domestic animals will be highly helpful in diverting the attention to take necessary actions for control and management of the disease [9]. Moreover, prevalence of toxoplasmosis in domestic animals of Pakistan has been investigated by various authors [9-11]. Further, toxoplasmosis in domestic animals in different parts of Khyber Pakhtunkhwa (KP) is questionable to date. The present research, therefore, was planned to find out the seroprevalence of toxoplasmosis and to assess the potential risk factors for it in cattle of District Dir Upper (DU), KP and Pakistan.

Dir is a mountainous area in the north of KP. Before merging into Pakistan, the whole Dir was a princely state ruled by Nawab Shah Jehan Khan. Dir was declared as a district of Pakistan in 1970. Dir Upper became a separate district in 1996 when the whole Dir was divided into upper and lower districts. The district is administratively divided into six Tehsils and 28 union councils. Main River of the district is River Panjkora which originates from Dir Kohistan. Tophography of the district is mountainous. The climate is humid subtropical. Summer is moderate and warm. Winter is very cold and severe. Rainfall is received throughout the year [12]. According to livestock census, there were 232,013 cattle in DU (Figure 1).

\section{Materials and Methods}

\section{Study area}

The present research was conducted in Dir Upper (DU) from January to May 2015. DU is one of the 24 districts in the northern part of KP, Pakistan. The district is situated at $35.21^{\circ}$ north latitude and $71.88^{\circ}$ east longitude in Hindukush Mountains along the Afghanistan border between Chitral, Bajaur Agency and Dir Lower. Mean elevation of the district from the sea level is $1,399 \mathrm{~m}$ and total area is $3,699 \mathrm{~km}^{2}$. According to population census (1998), total population of DU was 575,858. Main income sources of the people are farming, trade and overseas working. In periphery of the district, women help their men in farming along with their household's duties (District Profile Dir Upper, Khyber Pakhtunkhwa, 2015; Figure 1).

\section{Questionnaire survey}

A questionnaire was prepared to include all information about sex and age of animal, area from where the sample were collected, number of pregnancies and history of abortion. In order to assess the potential risk factors for toxoplasmosis, information such as: a) the presence of cats, F. catus in households (no feral cats were present in this area); b) source of drinking water (stagnant water source, e.g., pond or dam; running water source, e.g., river or streams etc.); c) type of cattle management (extensive: daily grazing in favorable weather conditions and returning to home at night or daily grazing with returning to home only in bad weather; intensive: animal housed day and night) were also noted on questionnaire at the time of blood collection. 

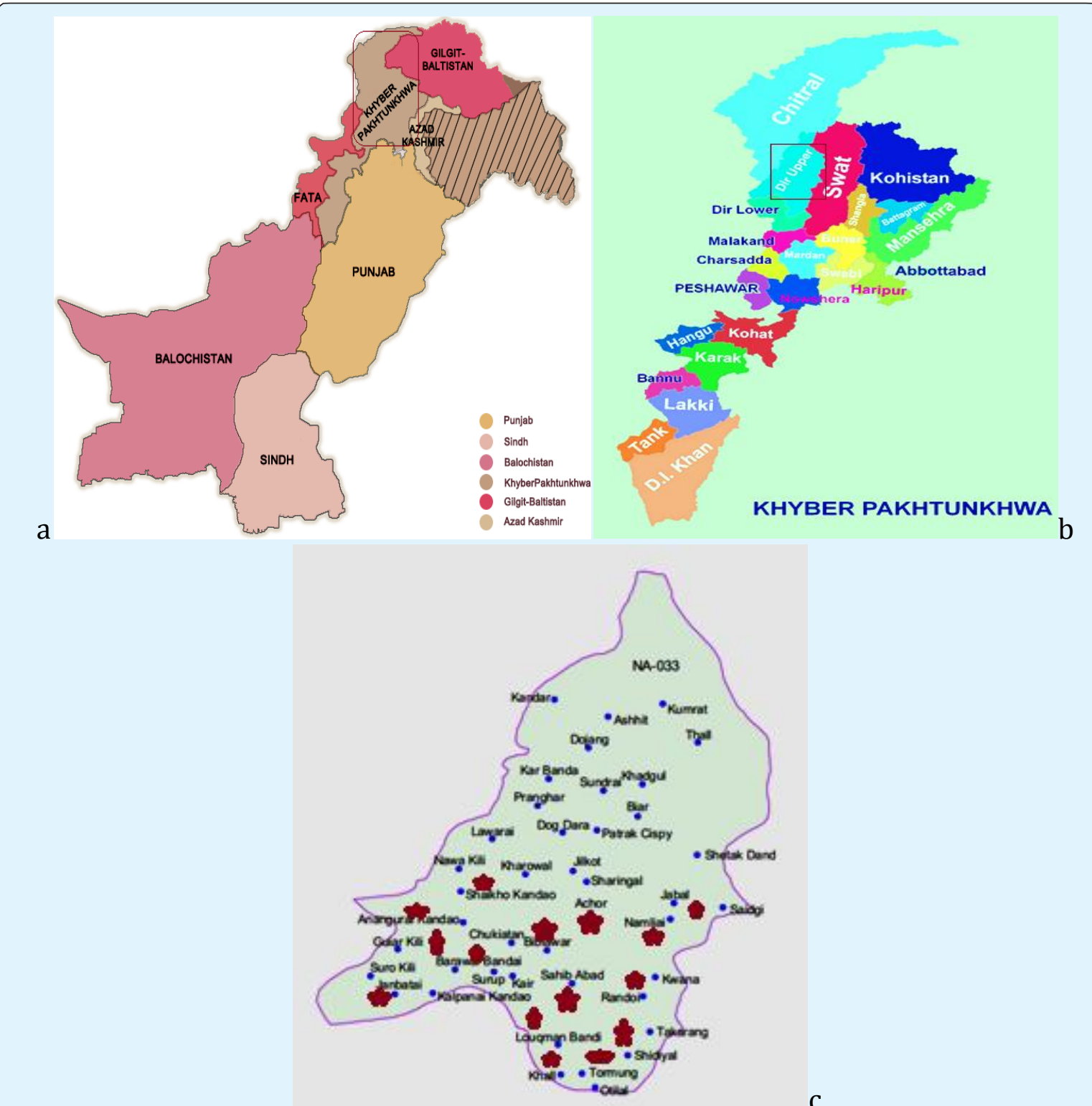

C

Figure 1: Map of the study area from where the blood samples were collected for the current research during January-May 2015; a: map of Pakistan [13];b: map of Khyber Pakhtunkhwa [14]; c: map of Dir Upper [15]; red stars show quadrates of study area

\section{Blood collection}

Blood samples $\left(\mathrm{n}_{\mathrm{ss}}=250\right)$ from both males ( $\left.\mathrm{n}_{\text {male }}=86\right)$ and females $\left(\mathrm{n}_{\text {female }}=164\right)$ B. indicus were randomly collected from different farm sample $\left(\mathrm{n}_{\text {farm }}=15\right)$ areas of DU.

\section{Serum separation}

Serum was separated from blood samples by centrifugation at 3,500 rpm for 5 minutes at room temperature. The serum samples were then immediately tested for antibodies against $T$. gondii by using commercially available Toxo-Latex Test kits ${ }^{\circledR}$ (Toxocell Latex Slide Agglutination, 100 tests, manufactured by 


\section{Open Access Journal of Veterinary Science \& Research}

DiaTech Diagnostic Technologies, Salerno, Italy). The test was performed according to the procedure described by the manufacturer. Agglutination at 1:16 was considered positive. In case of agglutination at 1:16 dilution, serial dilutions at 1:32, 1:64 and 1:128 were prepared and tested again.

\section{Data analysis}

The data were analyzed through Chi-square test with a confidence interval of 95\% using Statistical Package for Social Sciences (SPSS) version 16. True prevalence has been calculated, by taking into account both sensitivity $(100 \%)$ and specificity $(82.2 \%)$ of the test kit; sensitivity and specificity values reported by the manufacturer [16]; true prevalence was calculate according to formula provided [17-19].

\section{Results}

In the current research, seroprevalence and risk factors of toxoplasmosis in cattle (cows), Bos indicus of DU, KP and Pakistan were determined.

Thirty-four Bos indicus out of 250 were found infected with T. Gondii showing an overall prevalence of $14 \%$. Titers of antibodies to T. gondii were recorded up to maximum dilution of 1:64. Rate of infection in descending order at different dilutions was 1:16>1:32>1:64>1:128 (Figure 2).

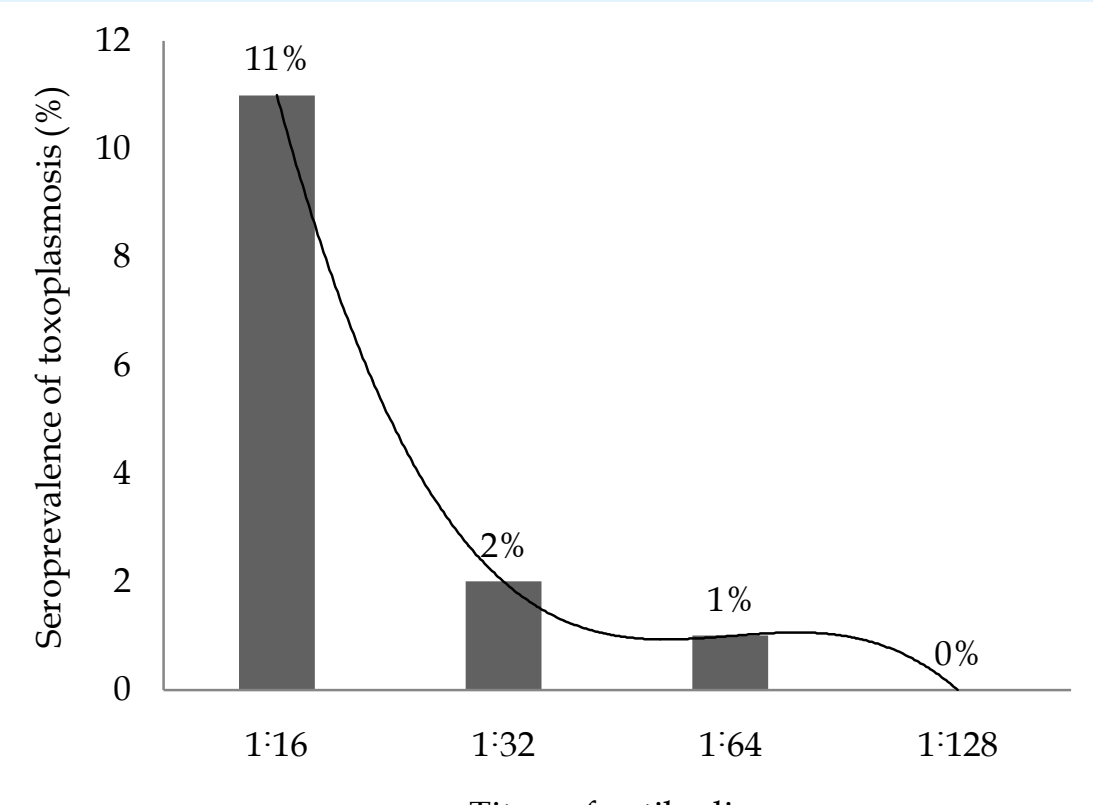

Titers of antibodies

Figure 2: Seroprevalence of toxoplasmosis at different dilutions of sera of the cows (cattle), Bos indicus Linnaeus in Dir Upper, Khyber Pakhtunkhwa, Pakistan during January-May 2015; serum samples $(\mathrm{nt}=250)$ were tested by using commercially available Latex Agglutination Test (LAT) Kits ${ }^{\circledR}$; agglutination at 1:16 dilution was considered positive; serial three-fold dilutions at 1:32, 1:64 and 1:128 were prepared in case of agglutination at $1: 16$ and tested again; \%: data are shown in percentage; trend line: polynomial.

Association of toxoplasmosis with sex of tested $B$. indicus showed that infection was $4 \%$ higher in males $\left(\mathrm{n}_{\mathrm{m}}=86\right)$ compared to females $\left(\mathrm{n}_{\mathrm{f}}=164\right)$. No significant difference was recorded between toxoplasmosis and sex of $B$. indicus, i.e., $\mathrm{P}>0.05$ (Table 1 ). 


\section{Open Access Journal of Veterinary Science \& Research}

\begin{tabular}{|c|c|c|c|c|c|}
\hline S.No & $\operatorname{Sex}^{1}$ & $\mathbf{n}^{2}$ & $\begin{array}{c}\text { Positive }(\%)^{3,4} \text { (apparent } \\
\text { prevalence) }\end{array}$ & Negative $(\%)^{3,4}$ & $\begin{array}{c}\text { True prevalence } \\
(\%)^{5}\end{array}$ \\
\hline 1 & Male & 86 & 16 & 84 & 0.536 \\
\hline 2 & Female & 164 & 12 & 88 & 0.514 \\
\hline 3 & Total & 250 & 14 & 86 & 0.525 \\
\hline
\end{tabular}

${ }^{1}$ Serum samples were tested by using commercially available Latex Agglutination Test (LAT) Kits ${ }^{\circledR}$; agglutination at 1:16 dilution was considered positive

2n: sample size (blood samples collected from number of B. indicus)

${ }^{3}$ Data were analyzed statistically by using Statistical Package for Social Sciences (SPSS) version 16 and were significant at $\mathrm{P}<0.05$

${ }^{4}$ Pearson chi-square test was used to find association between toxoplasmosis and sex of B. indicus; \%: data are shown in percentage; for the present data df: $1 ; \chi^{2}: 0.80 ; \mathrm{P}: 0.24$

${ }^{5}$ True prevalence has been calculated, by taking into account both sensitivity (100\%) and specificity (82.2\%) of the test kit; sensitivity and specificity values reported by the manufacturer [16] ; true prevalence was calculate according to formula provided [17-19]

Table 1: Association of toxoplasmosis with sex of the cows (cattle), Bos indicus Linnaeus in Dir Upper, Khyber Pakhtunkhwa, Pakistan during January-May, $2015^{1}$.

In order to find out the association of toxoplasmosis with age of $B$. indicus and to facilitate the experiment, they were divided into 3 age groups, $\mathrm{G}_{1}$ : aged 1-4 years; $\mathrm{G}_{2}$ : aged 5-8 years; $G_{3}$ : aged 9-12 years. A higher prevalence rate was observed in $\mathrm{G}_{1}$ and $\mathrm{G}_{3}$. Infection rate in descending order was: $\mathrm{G}_{1}>\mathrm{G}_{3}>\mathrm{G}_{2}$. There was no significant difference between toxoplasmosis and age of $B$. indicus at $\mathrm{P}<0.05$ (Table 2).

\begin{tabular}{|c|c|c|c|c|c|}
\hline S.No & Age groups & $\mathbf{n}^{\mathbf{2}}$ & $\begin{array}{c}\text { Positive (\%) } \\
\text { prevalence) }\end{array}$ & Negative (\%) $^{\mathbf{6}}$ & $\begin{array}{c}\text { True prevalence }^{\mathbf{3}} \\
\mathbf{( \% )}^{\mathbf{7}}\end{array}$ \\
\hline 1 & $\mathrm{G}_{1}{ }^{2}$ & 76 & 16 & 84 & 0.536 \\
\hline 2 & $\mathrm{G}_{2}{ }^{2}$ & 52 & 7 & 93 & 0.487 \\
\hline 3 & $\mathrm{G}_{3}{ }^{2}$ & 122 & 15 & 85 & 0.531 \\
\hline 4 & $\mathrm{~T}^{4}$ & 250 & 14 & 86 & 0.525 \\
\hline
\end{tabular}

${ }^{1}$ Serum samples were tested by using commercially available Latex Agglutination Test (LAT) Kits ${ }^{\circledR}$; agglutination at $1: 16$ dilution was considered positive

${ }^{2} \mathrm{G}_{1}: 1-4$ years, $\mathrm{G}_{2}: 5-8$ years, $\mathrm{G}_{3}: 9-12$ years

${ }^{3} \mathrm{n}$ : sample size (blood samples collected from number of $B$. indicus in each age group)

${ }^{4} \mathrm{~T}$ : total sample size (blood samples collected from total number of B. indicus

${ }^{5}$ Data were analyzed statistically by using Statistical Package for Social Sciences (SPSS) version 16 and were nonsignificant at $\mathrm{P}<0.05$

${ }^{6}$ Pearson chi-square test was used to find association between toxoplasmosis and age of cattle; \%: data are shown in percentage; for the present data df: $2 ; \chi^{2}: 1.99 ; \mathrm{P}<0.37$

${ }^{7}$ True prevalence has been calculated, by taking into account both sensitivity (100\%) and specificity (82.2\%) of the test kit; sensitivity and specificity values reported by the manufacturer [16] ; true prevalence was calculate according to formula provided [17-19]

Table 2: Association of toxoplasmosis with age of the cows (cattle), Bos indicus Linnaeus in District Dir Upper, Khyber Pakhtunkhwa, Pakistan during January-May $2015^{1}$.

Association of toxoplasmosis with number of pregnancies was also determined. The highest rate of infection was observed in B. indicus with 5 pregnancies and the lowest with 3 and 4 pregnancies. Infection rate in descending order was: $5>1>2>0=3=4$. However, 
statistically, there was no significant association between toxoplasmosis and number of pregnancies, i.e., $\mathrm{P}>0.05$ (Figure 3). Moreover, relationship of toxoplasmosis with abortion was statistically non-significant as $\mathrm{P}>0.05$. Furthermore, none of the tested B. indicus showed history of abortion.

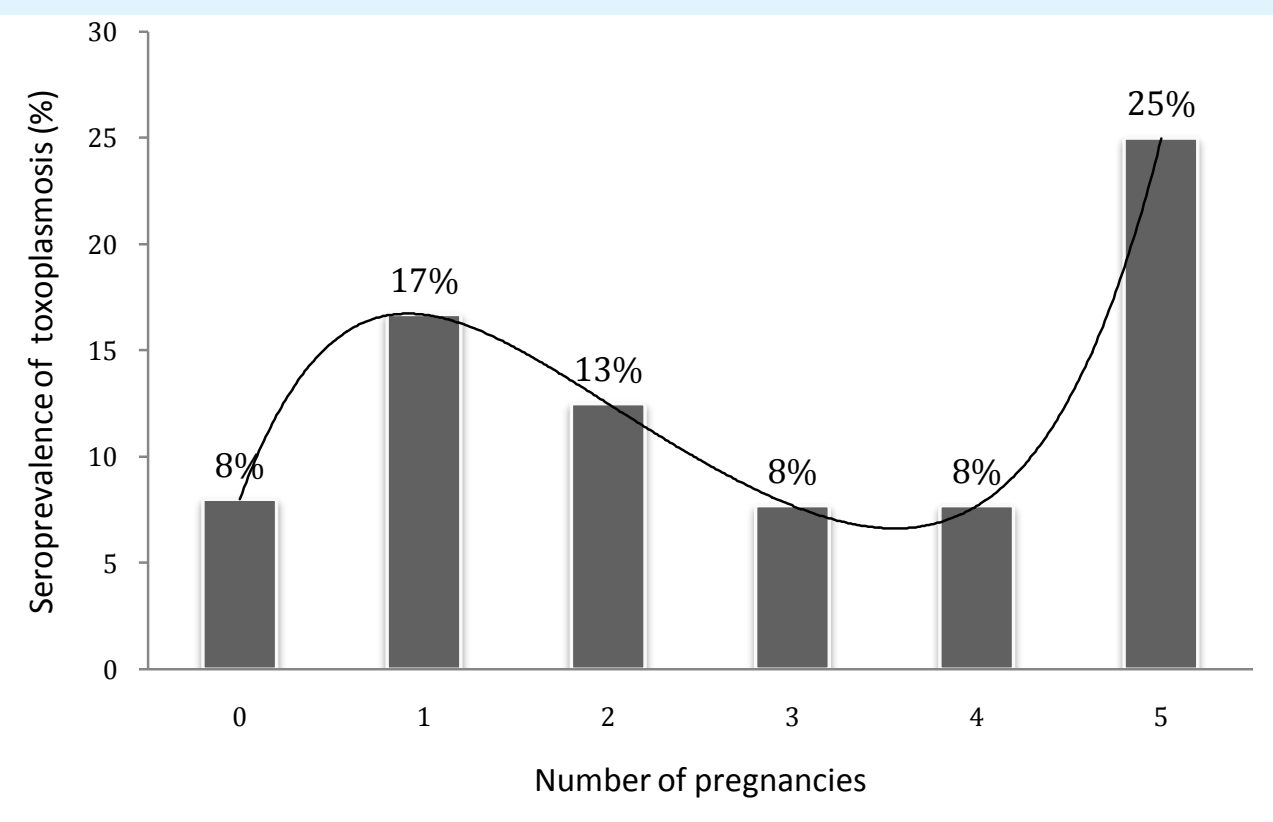

Figure 3: Association of toxoplasmosis with number of pregnancies of the cows (cattle), Bos indicus Linnaeus in Dir Upper, Khyber Pakhtunkhwa, Pakistan during January-May 2015; serum samples were tested by using commercially available Latex Agglutination Test (LAT) Kits ${ }^{\circledR}$; agglutination at 1:16 dilution was considered positive; data were analyzed statistically by Statistical Package for Social Sciences (SPSS) version 16 and were non-significant at $\mathrm{P}<0.05$; Pearson chi-square test was used to find association between toxoplasmosis and number of pregnancies of B. indicus; \%: data are shown in percentage; trend line: polynomial; for current data df: $7 ; \chi^{2}: 0.80 ; \mathrm{P}<0.24$.

\section{Risk Factors}

To find out potential risk factors for toxoplasmosis in $B$. indicus from District DU, the following risk factors: a) presence of $F$. catus in households; b) source of drinking water; c) type of cattle management of $B$. indicus were analyzed statistically for acquiring infection with $T$. gondii. All the infected $B$. indicus had contacts with $F$. catus. However, statistically there was no association between presence of $F$. catus in households and infection in $B$. indicus at $\mathrm{P}<0.05$. Additionally, data revealed that the most of examined $B$. indicus used running water for drinking as compared to stagnant water. The infection rate recorded was double in $B$. indicus that used running water compared to stagnant water. However, no statistically significant association was found between infection and source of drinking water, i.e., $\mathrm{P}>0.05$.

Similarly, whole of $B$. indicus in study area were reared either under extensive or intensive management systems. Majority of $B$. indicus were reared under intensive system. However, the infection rate was higher in $B$. indicus reared under extensive system compared to those reared under intensive system. Difference between management systems and toxoplasmosis was statistically nonsignificant, i.e., $\mathrm{P}<0.05$ (Table 3 ). 


\section{Open Access Journal of Veterinary Science \& Research}

\begin{tabular}{|c|c|c|c|c|c|c|}
\hline S.No & \multicolumn{2}{|c|}{ Risk factors } & $\mathbf{N}^{4}$ & $\begin{array}{l}\text { Positive }{ }^{5} \text { (apparent } \\
\text { prevalence) }\end{array}$ & $\begin{array}{l}\text { Negative } \\
(\%)^{6}\end{array}$ & $\begin{array}{l}\text { True prevalence } \\
(\%)^{7}\end{array}$ \\
\hline \multirow{2}{*}{1} & \multirow{2}{*}{$\begin{array}{l}\text { Cat, Feliscatus in } \\
\text { households }\end{array}$} & present & 240 & 34 & 14 & 0.636 \\
\hline & & absent & 10 & 0 & 0 & 0.448 \\
\hline \multirow{2}{*}{2} & Source of drinking & stagnant & 74 & 6 & 8 & 0.481 \\
\hline & Water & running & 176 & 28 & 16 & 0.603 \\
\hline \multirow{2}{*}{3} & \multirow{2}{*}{ Type of management } & Extensive $^{2}$ & 98 & 18 & 18 & 0.547 \\
\hline & & Intensive $^{3}$ & 152 & 16 & 11 & 0.536 \\
\hline \multicolumn{7}{|c|}{1 Data were collected by preformed printed proforma } \\
\hline \multicolumn{7}{|c|}{$\begin{array}{l}\text { 2Extensive: daily grazing in favorable weather conditions and returning to home at night or daily grazing with } \\
\text { returning to home only in bad weather }\end{array}$} \\
\hline \multicolumn{7}{|c|}{$\begin{array}{l}\text { 3intensive: B.indicus housed day and night; chi-square test was used to find association between toxoplasmosis and } \\
\text { risk factors }\end{array}$} \\
\hline \multicolumn{7}{|c|}{${ }^{4}$ n: sample size (blood samples collected from number of B. indicus) } \\
\hline \multicolumn{7}{|c|}{$\begin{array}{l}\text { 5Data were analyzed statistically by using Statistical Package for Social Sciences (SPSS) version } 16 \text { and were } \\
\text { significant at } \mathrm{P}<0.05\end{array}$} \\
\hline \multicolumn{7}{|c|}{$\begin{array}{l}\text { 6Pearson chi-square test was used to find association between toxoplasmosis and risk factors; \%: data are shown in } \\
\text { percentage; for presence of } F \text {. catusdf: } 1 ; \chi^{2}: 1.64 ; \text { P: } 0.23 \text {; for source of water df: } 1 ; \chi^{2}: 2.70 ; \text { P: } 0.07 \text {; for type of } \\
\text { management df: } 1 ; \chi^{2}: 3.12 ; \text { P: } 0.06\end{array}$} \\
\hline \multicolumn{7}{|c|}{$\begin{array}{l}\text { 7True prevalence has been calculated, by taking into account both sensitivity }(100 \%) \text { and specificity }(82.2 \%) \text { of the } \\
\text { test kit; sensitivity and specificity values reported by the manufacturer [16] }\end{array}$} \\
\hline \multicolumn{7}{|c|}{ true prevalence was calculate according to formula provided [17-19] } \\
\hline
\end{tabular}

Table 3: Risk factors for toxoplasmosis in the cows (cattle), Bos indicus Linnaeus from Dir Upper, Khyber Pakhtunkhwa, Pakistan during January-May $2015^{1}$

\section{Discussion}

In the present study, the seroprevalence of toxoplasmosis in B. indicus in DU, KP, Pakistan was determined during January-May 2015.

An overall prevalence rate of $14 \%$ was recorded. Various authors have reported different prevalence rate (apparent and true) from different regions within Pakistan and from other countries. In cattle, overall prevalence of $43 \%$ was reported by Tasawar et al. [10] in Punjab Pakistan; 20\% by Shah et al. [9] in Mohmand Agency, Pakistan; $19.75 \%$ by Ahmad and Qyuum (2014) in Northern Punjab, Pakistan; $16.6 \%$ by Kalita and Sarmah [20] in Assam, India; $15.9 \%$ by Kadle [21] in Somalia; $13.7 \%$ by Matsuo et al. [22] in Japan; $3.1 \%$ by Gasior in Poland and $2.68 \%$ by Fajardo in Brazil. Prevalence of toxoplasmosis varies in different regions of the world due to difference in weather conditions, rearing practices, age of animals, life style and customs of people [23], differences in sensitivity and specificity of techniques used for diagnosis, number of felines in the area [24] and type of farm management [3]. Infection is common in areas having humid and warm climate compared to cold and dry regions, because these climatic conditions favor survival of the oocysts of T. gondii [25]. The overall prevalence of the present study varies from previous studies mentioned above. This variation may be due to differences in climatic conditions and serological techniques used in different studies.

During the present study, a higher infection rate (16\%) was recorded in B. indicus of males compared to females (12\%). Similar results were also reported in cattle by Fajardo et al. from Brazil and Elfahal et al. [26] from Sudan. However, in contrast to this, lower rate of infection in males was recorded by Kadle [21] in Somalia; Shah et al. [9] in Mohamed Agency, Pakistan and Tasawar et al. [10] in Punjab, Pakistan. Female cattle were more resistant to infections compared to males; because of the female sex hormone estrogen strengthens the immune system as compared to androgens in males. Androgens render males more susceptible to infections because of weakening their immune system. The difference in seroprevalence of toxoplasmosis in male and female $B$. indicus during the present research from previous conducted studies may be attributed to difference in sex hormones in both sexes. 
During the present study, the highest $16 \%$ of infection was recorded in young $B$. indicus. These results were in accordance with those of Tasawar et al. [10], who had also recorded the highest \% of infection in young cattle in Punjab Pakistan. Similarly, Elfahal et al. [26] in Sudan; Nematollahi and Moghddam in Iran and Holec-Gasior et al., [27] in Poland have reported higher infection rate in the same age group. Young cattle may acquire antibodies from mothers, therefore, showed higher infection rate. Also cattle lost antibodies with advancement in age unless they were not re-infected [28]. The reason for higher infection in young than adults in the present study from above mentioned studies may be due to congenital transmission of antibodies from mother to young ones.

At the present, a higher infection rate was recorded in $B$. indicus that had F. catus in their vicinity. Fajardo et al. have also observed significant correlation between cattle seropositivity and presence of $F$. catus on the farms, while they investigated toxoplasmosis in cattle in Brazil. Similarly, [29] have also reported a higher prevalence of toxoplasmosis in sheep, Ovis Aries L 1758 in Brazil, where F. catus were present in the farms. Felis catus acted as definitive host for T. gondii and were necessary for the completion of its life cycle [25]. The environment contaminated with the presence of infected $F$. catus and thus the risk of infection increased [30]. Like the above studies, contamination of environment with $F$. catus faeces may also be responsible for higher infection rate in $B$. indicus in the current research.

Toxoplasma gondii oocysts remained alive in cold water for up to 54 months. Therefore, contaminated water led to infection, if used unfiltered [6]. Drinking water must be considered as a source for transmission of $T$. gondii infection [29]. During the present research, a higher \% of infected $B$. indicus using running water was recorded. The reason for this may be that most of $B$. indicus in DU used running water for drinking, as it was easily available. The present results were in accordance to those of Andrade et al., [29], who investigated sero prevalence of toxoplasmosis in 0 . aires in Brazil and reported a higher infection in $O$. Aries using running water for drinking purposes. Pinheiro et al., [31] also pointed out running water as a risk factor for toxoplasmosis. However, in contrast to the present findings, Cen-Goga et al., [32] reported a higher infection in 0 . aries used stagnant water for drinking purposes. Similar to the fore-mentioned studies, the reason for higher infection in B. indicus using running water during the present study may be due to easily available.

Perveen FK and Shah H. Seroprevalence and Risk Factors for Toxoplasmosis in the Cows (Cattle), Bos indicus Linnaeus (Mammalia: Eutheria) from Dir Upper, Khyber Pakhtunkhwa, Pakistan. J Vet Sci Res 2016, 1(3): 000117.
In the current study, animals managed under extensive system were found to be more infected compared to those reared under intensive system. These results corresponds to those of Cenci-Goga et al. [32] and Puije et al. [33], who investigated seroprevalence in 0 . aries in Italy and Ghana, respectively. Animals reared under extensive system had more chances to be in contact with oocysts of $T$. gondii excreted in F. catus faeces. Therefore, these animals had greater chances to acquire infection [34]. Similar to these studies, the same reason may also be responsible for higher infection in $B$. indicus reared under extensive management system at the present.

Dir Upper is a mountainous region; therefore, access to all the remote areas of the district was not possible. The area remained covered with snow and temperature was very low during the winter season. Moreover, most of people in DU involved with B. indicus were illiterate and did not know scientific ways of rearing the cattle. Most of the cattle were kept in unhygienic conditions. Data for the present research was, therefore, collected from the lower parts of DU. Questionnaire was filled by asking the questions from owners of cattle orally. Studies about the seroprevalence of toxoplasmosis in animals using molecular methods such as Polymerase Chain Reaction (PCR) will be of great help in confirming the seropositivity to T. gondii.

\section{Conclusion}

In B. indicus of DU, toxoplasmosis is more prevalent in males, in 1-4 years age group and in females having 5 times pregnancies.

\section{Recommendations}

In order to lower the incidence and spreading of toxoplasmosis in B. indicus in DU, suitable prophylactic measures should be undertaken. Also the public especially the farmers should be educated about the spreading routes and acquisition of toxoplasmosis.

\section{References}

1. Tasawar Z, Aziz F, Lashari MH, Shafi S, Ahmad M, et al. (2012) Seroprevalence of human Toxoplasmosis in Southern Punjab, Pakistan. Pakistan Journal of Life and Social Sciences 10(1): 48-52. 


\section{Open Access Journal of Veterinary Science \& Research}

2. Kader JM, Al-Khayat ZAY (2013) Serodiagnosis of toxoplasmosis in sheep and goats in Erbil city, Iraq. Iraqi Journal of Veterinary Sciences 27(1): 21-23.

3. Dubey JP, Jones, JL (2008) Toxoplasma gondii infection in humans and animals in the United States. International Journal of Parasitology 38: 1257-1278.

4. Zhou D, Zhao F, Lu P, Xia H, Xu M, et al. (2012) Seroprevalence of Toxoplasma gondii infection in dairy cattle in southern China. Parasites and Vectors, Biomedical Center 5: 48-52.

5. Dalbou MA, Ababneh MM, Giadinis ND, Lafi SQ (2010) Ovine and caprine toxoplasmosis (Toxoplasma gondii). Iranian Journal of Veterinary Science and Technology 2(2): 61-76.

6. Dubey JP, Lindsay DS, Speer CA (1998) Structures of Toxoplasma gondiitachyzoites, bradyzoites, and sporozoites and biology and development of tissue cysts. Clinical Microbiology Reviews 11(2): 267-299.

7. Fajardo HV, Dávila S, Bastos RR, Cyrino CD, Detoni M, et al. (2013) Seroprevalence and risk factors of toxoplasmosis in cattle from extensive and semiintensive rearing systems at Zona da Mata, Minas Gerais state, Southern Brazil. BioMed Central. Parasites and Vectors 6(1): 191-199.

8. Chaudhary ZI, Ahmad RS, Hussain SMI, Shakoori AR (2006) Detection of Toxoplasma gondii infection in butchers and buffaloes by Polymerase Chain Reaction and Latex Agglutination Test. Pakistan Journal of Zoology 38(4): 333-336.

9. Shah M, Zahid M, Alam A, Asmat P, Kausar A, et al. (2013) Seroprevalence of Toxoplasma gondii infection in domestic animals of Mohmand Agency, Pakistan. Journal of Coastal Life Medicine 1(1): 70-73.

10. Tasawar Z, Shafiq Z, Lashari MH, Aziz F (2013) Seroprevalence of Toxoplasma gondii in cattle, Punjab, Pakistan. Global Veterinarian 11 (5): 681684.

11. Ramzan MM, Akhtar M, Hussain I, Muhammad F, SkaSawickaa EH, et al. (2008) Seroprevalence of Toxoplasma gondii in sheep and goats in area of Rahim Yar Khan (Punjab), Pakistan. 13 ${ }^{\text {th }}$ International Congress of Infectious Diseases, 19th June, Kualalumpur, Malaysia 5: 339-342.
12. http//www.dirvalley.com.

13. Online,(2015)

http://nationalheritage.gov.pk/provinces.html; (accessed: 27/7/2015)

14. Online, (2015)

http://nationalheritage.gov.pk/provinces.html; (accessed: 27/7/2015).

15. http://uelect.org.pk/constituency/33/NA33+Upper+Dir

16. http://www.biokit.com/productos/reagents/rapidtest/toxocell-latex.aspx.

17. Reiczigel J, Földi J, Ózsvári L (2010) Exact confidence limits for prevalence of a disease with an imperfect diagnostic test. Epidemiology and Infection 138(11): 1674-1678.

18. Estimated true prevalence and predictive values from survey_testing. http://www.biokit.com/productos/reagents/rapidtest/toxocell-latex.aspx:

19. Adjustment of a Prevalence Estimate for Misclassification.

http://epitools.ausvet.com.au/content.php?page=Tru ePrevalence;

20. Kalita M, Sarmah PC (2015) Sero-prevalence of Toxoplasma gondii in cattle from Assam. International Journal of Recent Scientific Research 6(3): 32233225.

21. Kadle AAH (2014) Sero-prevalence of toxoplasmosis in domestic animals in Benadir Region, Somalia. Open Journal of Veterinary Medicine 4: 170-174.

22. Matsuo K, Kamai R, Uetsu H, Goto H, Takashima Y, et al. (2014) Seroprevalence of Toxoplasma gondii infection in cattle, horses, pigs and chickens in Japan. Parasitol Int 63(4): 638-639.

23. Tenter AM, Heckeroth AR, Weiss LM (2000) Toxoplasma gondii: from animals to humans. Int J Parasitol 30(12-13): 1217-1258.

24. Shaapan RM, El-Nawawi FA, Tawfik MAA (2008) Sensitivity and specificity of various serological tests for the detection of Toxoplasma gondii infection in 
naturally infected sheep. Vet Parasitol 153(3-4): 359362.

25. Dubey JP (2010) Toxoplasmosis of animals and humans. CRCPress Inc, Bocsa Raton, New York, USA 2: 1-313.

26. Elfahal AM, Elhassan AM, Hussien MO, Enan KA, Musa AB, et al. (2013) Seroprevalence of Toxoplasma gondii in dairy cattle with reproductive problems in Sudan. Hindawi Publishing Corporation ISRN Veterinary Science 10: 1155-1160.

27. Holec L, Drapala D, Dominiak B, Kur J (2013) Epidemiological study of Toxoplasma gondii infection among cattle in Northern Poland. Annals of Agricultural and Environmental Medicine 20(4): 653656.

28. Dubey JP, Beattie CP (1988) Toxoplasmosis of animals and man. CRC Press Inc, Boca Raton, New York, USA 1: 220-225.

29. Andrade MMC, Carneiro M, Medeiros AD, Neto VA, Vitor RWA (2013) Seroprevalence and risk factors associated with ovine toxoplasmosis in Northeast Brazil. Parasite 20: 20-25.

30. Weigel RM, Dubey JP, Siegel AM, Kitro UD, Mannelli MA, et al. (1995) Risk factors for transmission of Toxoplasma gondii on swing farms in Illinois. Journal of Parasitology 81(5): 736-741.
31. Pinheiro JW, Mota RA, Oliveira AAF, Faria EB, Gondi LFP, et al. (2009) Prevalence and risk factors associated to infection by Toxoplasma gondii in ovine in the State of Alagoas, Brazil. Parasitology Research 105(3): 709-715.

32. Cenci-Goga BT, Ciampelli A, Sechi P, Veronesi F, Moretta I, et al. (2013) Seroprevalence and risk factors for Toxoplasma gondii in sheep in Grosseto district, Tuscany, Italy. Biomedical Central, Veterinary Research 9: 25-32.

33. Puije WNA, Bosompem KM, Canacoo EA, Wastling JM, Akanmor BD (2000) The prevalence of antiToxoplasma gondii antibodies in Ghanaian sheep and goats. Acta Tropica 76(1): 21-26.

34. Anderlini GA, Mota RA, Faria EB, Cavalcanti EF, Valenca RMB, et al. (2011) Occurrence and risk factors associated with infection by Toxoplasma gondii in goats in the state of Alagoas, Brazil. Revista da SociedadeBrasileira de Medicina Tropical 44: 157162.

35. Ahmad N, Qayyum M (2014) Seroprevalence and risk factors for toxoplasmosis in large ruminants in northern Punjab, Pakistan. The Journal of Infection in Developing Countries 8(8): 1022-1028. 